\title{
Scribal Correction Dots on an Unpublished Elephantine Aramaic Papyrus Fragment
}

\author{
James D. Moore* \\ Theologische Fakultät, Humboldt-Universität zu Berlin; Ägyptisches Museum \\ und Papyrussammlung, Staatliche Museen zu Berlin, SPK, Berlin, Germany \\ james.moore@hu-berlin.de
}

\begin{abstract}
In a box of unpublished Aramaic papyri from the 1906-1907 German excavations of Elephantine there is a small fragment (p. 23141) that uses scribal marks in a margin or vacat to identify a textual edit. This is the first example of Aramaic editorial marks of this type from the Persian period, and demonstrates a previously unidentified scribal practice.
\end{abstract}

\section{Keywords}

scribal culture - Elephantine - papyri - Glossenkeil - punctuation

The Ägyptisches Museum und Papyrussammlung of the Staatliche Museen $\mathrm{zu}$ Berlin holds a box of unpublished Aramaic fragments from the German excavations of $1906-1907 .{ }^{1}$ In the box a small fragment was found that now

* Research for this article has been made possible by the European Research Council (ERC)funded project, Localizing 4,ooo Years of Cultural History. Texts and Scripts from Elephantine Island in Egypt, directed by Verena Lepper as well as by the Deutsche Forschungsgemeinschaft (DFG)-funded project, Elephantine in Context, directed by Bernd Schipper.

1 On 8 August 2017 at the International Society of Biblical Literature meeting in Berlin, Verena Lepper reported on the state of her ERC-team's work on creating a database of Elephantine documents. She gave the first public announcement of the rediscovery of this "Aramaic box". Details of the Aramaic box, its history, and its contents will be published in coming years. The box contains papyrus fragments of various sizes and in various states of preservation.

(C) JAMES D. MOORE, 2018 | DOI: 10.1163/17455227-01601006

This is an open access article distributed under the terms of the prevailing CC-BY-NC license at the time of publication. 
bears the museum number p. 23141. ${ }^{2}$ It exhibits a unique Aramaic scribal practice: the use of two vertically aligned dots on either side of a scribal correction. This article will study the fragment in comparative perspective and demonstrate that while the practice of using dots as a scribal notation shares minor formal similarities with first millennium Akkadian scribal practices, this fragment exhibits an otherwise unknown Aramaic scribal technique of using a pair of vertically aligned dots placed on either side of a letter to indicate a correction.

Scribal corrections and editorial activity among the published Elephantine Aramaic papyri fall into two general types. The first type involves the correction of written errors in a text. ${ }^{3}$ When Aramaic scribes made mistakes while composing documents, they typically either (a) erased and skipped over the erasure (e.g., TAD B.3.6.13), (b) erased and wrote over the erasure (e.g., TAD в.3.2.3), or (c) blotted out the error and skipped over the blot (e.g., TAD B.3.6). ${ }^{4}$

The second type of correction involves the addition of missing content to a document. When adding missing material, scribes frequently made additions in the margin or interlinear space directly above the place in which the text was missing. ${ }^{5}$ Missing corrections include the addition of (a) individual letters (e.g., TAD A.6.2.8), (b) complete words (e.g., TAD C.1.5), or (c) even complete lines (e.g., TAD B.3.3.14).

An unpublished fragment from the Aramaic box exhibits a new type of scribal correction. The fragment p. 23141 is a small piece of papyrus that measures approximately $2.8 \mathrm{~cm}$ wide by $2.5 \mathrm{~cm}$ high. The text is written on both sides as an opistograph, that is, the writer flipped the document across its vertical axis (from-side-to-side) and continued the composition from the front to the back. No evidence of sheet-joins survives, and as with many of the Elephantine papyri, this fragment is of such high quality that it is difficult to determine the recto and verso based on material grounds. Because the fragment is from

2 Staatliche Museen zu Berlin-Ägyptisches Museum und Papyrussammlung, Inv. p. 23141, photographs by the author and E RC papyrus conservator, Tzulia Siopi. All figures in this article are reprinted with the permission of Verena Lepper, Curator for Egyptian and Oriental Papyri, SPK, SMB, ÄMP.

3 For a discussion of errors see B. Porten, 'Aramaic Papyri and Parchments: A New Look', $B A 42$, no. 2 (1979), pp. 74-104 (82); idem, 'The Revised Draft of the Letter of Jedaniah to Bagavahya', in M. Lubetski, C. Gottlieb, and S. Keller (eds.), Boundaries of the Ancient Near Eastern World: A Tribute to Cyrus H. Gordon (JSOTSup, 273, Sheffield: Sheffield Academic Press, 1988) pp. 230242.

4 Distinguishing between blots and erasures in which the ink has been smeared can be difficult.

5 For a rare example of a sub-linear addition, see $T A D$ B.3.4.7. 
an opistograph and because the ink is best preserved on the side with the text written horizontally to the fibres, it is assumed that the better-preserved side is the recto. ${ }^{6}$

The fragment reads:
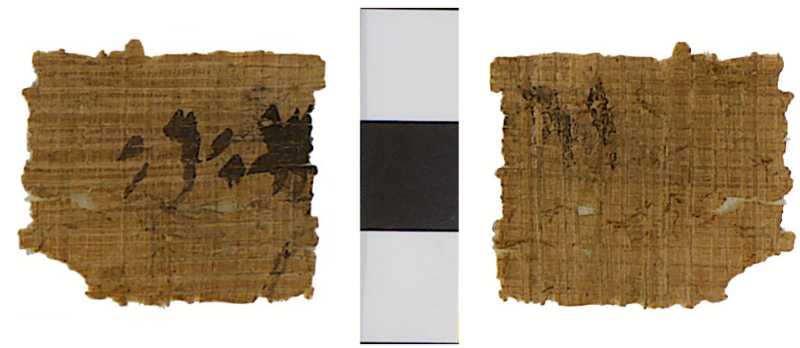

FIGURE 1 p. 23141 recto and verso (paper backing visible)

\begin{tabular}{|c|c|}
\hline Recto & ] [ [אין \\
\hline Verso & [ ז/וס?־] \\
\hline
\end{tabular}

The recto contains a blotted-out character followed by a waw, which sits in a margin or vacat and between two colon-like marks. The blotted character is difficult to decipher, but under infrared magnification, the ink strokes become slightly more apparent. ${ }^{7}$ It looks as though an $\boldsymbol{\aleph}$ or ' was originally written and then erased. ${ }^{8} \mathrm{~A}$ i or $\uparrow$ was written over the erasure. Afterward, an $\aleph$ or marks used to blot out the character were written over the $\mathrm{r} / \mathrm{r}$. The writer then placed in the margin or vacat a letter between a pair of vertically aligned dots that resemble colons.

6 The genres of lists, literature, memoranda, and judicial texts are written parallel to the fibers on the recto and may continue as an opistograph in the Aramaic papyri from Egypt. Most papyrus contracts and letters are written transversa charta, and if writing appears on the verso, the document was flipped across its horizontal axis (i.e., top-to-bottom). For a discussion of papyrological terminology, see E.G. Turner, The Terms Recto and Verso: The Anatomy of the Papyrus Roll (Études de papyrologie et éditions de sources, 16, Brussels: Fondation Égyptolog, Reine Élisabeth, 1978).

7 The ink is carbon based and contains no traces of metal agents. Thus, the infrared spectrum helps to better see the ink, but the ultraviolet spectrum is of no value.

8 Traces of ink on the bottom right of the fragment's first line suggest that the first broken letter (the $\circ$ in the transcription) may have been a $\supset$, J, or $ת$. 
The letter between the colons appears to be a 1 , but the two sharp points on the character's head leaves some doubt. Great variation exists in the ductus and stance of waws used in Persian-period Aramaic from Egypt. ${ }^{9}$ Paleographically, the letter is similar to the $\mathrm{I} / \mathrm{T}$ that was previously corrected and also to that which appears on the verso. The letter between the scribal marks was written with a single downward stroke, but then the pen was lifted and a small head was added to the stroke. One might be tempted to read this as a $7 / 7$, but I am inclined to interpret the pen-lift and second stroke as an act of intentionally articulating the head of a l.
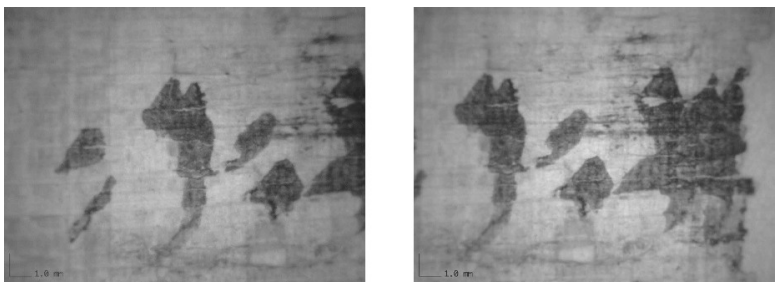

FIGURES $2 \mathrm{AB}$ Infrared microscopic photos, p. 23141 recto

The ink on the verso is more defaced than on the recto and is difficult to read. Under infrared magnification it appears that a margin ${ }^{10}$ is followed by a word

The paleography of each document should be considered on its own grounds, but for helpful discussions and script charts see P.T. Daniels, 'A Calligraphic Approach to Aramaic Paleography', JNES 43 (1984), pp. 55-68; R. Degen, 'Neue Fragmente aramaeischer Papyri aus Elephantine I', in R. Degen, W.W. Müller, and W. Röllig (eds.), Neue Ephemeris für semitische Epigraphik (2, Wiesbaden: Harrassowitz, 1974) pp. 71-78, pl. vi; idem, 'Neue Fragmente aramaeischer Papyri aus Elephantine II', in R. Degen, W.W. Müller, and W. Röllig (eds.), Neue Ephemeris für semitische Epigraphik (3, Wiesbaden: Harrassowitz, 1978) pp.1532, pl. ii; H. Lozachmeur, La collection Clermont-Ganneau: ostraca, épigraphes sur jarre étiquettes de bois (Mémoires de l' académie des inscriptions et belles-lettres, 35, Paris: de Boccard, 2006) pp. vol. 2, pl. 16-25; J. Naveh, 'The Development of the Aramaic Script', Ph.D. Diss. (Jerusalem: Hebrew University, 1966) drawings 3-8; idem, Development of the Aramaic Script (Proceedings of the Israel Academy of Sciences and Humanities, 5, Jerusalem: Israel Academy of Sciences and Humanities, 1970) Figs. 1-12, 21-51; A. Yardeni, 'Papyrological and Palaeographical Aspects of the Elephantine Documents', Maarav 21 (2014), pp. 151-167, 379-381.

10 The fragment contains edges (or vacats) on both the recto and verso. It is not common for the margins of an opistographic fragment to align on the recto and verso, as they do here. For one example see the so-called "Memphis Shipyard Journal" (TAD C.3.8.scroll iv $[\mathrm{AG} 12+18])$. 
that starts with either a i or $1 .{ }^{11} \mathrm{~A}$ second letter appears to be a $\mathrm{D}$ and only traces of a third letter survive.

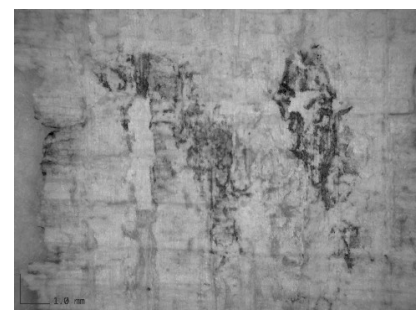

FIGURE 3

Infrared microscopic photo, p. 23141 verso

The two vertically aligned dots in the fragment appear to be intentional, and they represent, to-date, one of the few examples of editorial or punctuation marks used in Northwest Semitic texts in the first millennium BCE. Word dividers have long been known from Northwest Semitic inscriptions, and the oldest Aramaic and Akkadian bilingual inscription from Tell Fekherye (KAI 309) uses two vertically aligned dots as word dividers. ${ }^{12}$ Other early Aramaic inscriptions use a single-dot word divider. ${ }^{13}$ In the first millennium, however, word division was relegated to particular scripts and languages, and Persianperiod Aramaic had abandoned word dividers in favour of word spaces. ${ }^{14}$

Beyond the use of dots as word dividers, two vertically aligned dots were frequently used in two Northwest Semitic contexts, the el Amarna letters and Ugaritic texts. In the el Amarna letters, Canaanite scribes used the cuneiform Glossenkeil to gloss foreign words, generally with Canaanite terms. ${ }^{15}$ Gianto

11 It is possible that the stroke is the number 1. But numbers generally follow measurements. The letter and the number $20(3)$ are similar, but 20 always precedes 1 , thus I would expect 13. The characters $100(-)$, 1,000 $(x)$, and 10,000 ( $\$$ ) function adjectivally, i.e., they follow cardinal numbers. The second character on the verso does not resemble these numeric characters.

12 The editio princeps does not discuss the origin of the two-dot divider (A. Abou-Assaf, P. Bordreuil, and A.R. Millard, Le statue de Tell Fekherye et son inscription bilingue assyroaraméenne [Etudes assyriologiques 7 , Paris: Éditions recherche sur les civilisations, 1982]).

13 See KAI nos. 201-203, 214-221, 231, 236, 277, 310, 312, 314-315, 32O.

14 J. Naveh, 'Word Division in West Semitic Writing', IEJ 23 (1973), 206-208. In the second millennium вСЕ, the word-divider consisted of three vertically aligned dots at Lachish (p. 206), and a Phoenician inscription discovered in Saqqara, Egypt, which is nearly contemporary with the Elephantine papyri, uses the common single-dot word divider (p. 208 and cIS I no. 86).

15 A. Rainey, Canaanite in the Amarna Tablets: A Linguistic Analysis of the Mixed Dialect Used by the Scribes from Canaan (4 vols., HdO, 25, Leiden: Brill, 1996) pp. 1:35-36. 
has shown that Glossenkeile in the el Amarna letters provide the reader with correct pronunciations, equivalent Canaanite or Akkadian translations, more precise Canaanite renderings, more intensified Canaanite expressions, as well as a few other not yet identified functions. ${ }^{16}$ Similarly, van der Toorn has argued that glossed terms in these letters indicate that scribes checked their work by reading it. ${ }^{17}$ Thus, the Glossenkeile in el Amarna sources are editorial marks that facilitate reading and comprehension; they do not indicate mere orthographic errors. The Glossenkeile in texts from Ugarit similarly function as editorial markers within a bilingual context. ${ }^{18}$ At least two Ugaritic texts, however, use a rare mark apparently to identify a letter-correction, ${ }^{19}$ but at present there is no clear evidence connecting this rare second-millennium Ugaritic mark with Persian-period Aramaic. It is best explained as a coincidental scribal development in two separate scribal contexts.

Two vertically aligned dots used to edit or to punctuate a text do not appear again in Northwest Semitic documents (to my knowledge) until Qumran, in which the Aramaic text 4Q156 (Targum Leviticus) uses two vertically aligned dots as a clause divider. ${ }^{20}$ There is no evidence that the two dots in this later source are editorial; they merely punctuate the text, perhaps for liturgical purposes. A similar phenomenon is known from a Seleucid period cuneiform tablet from Uruk which appears to be written in the Aramaic language using cuneiform script (TU no. 58). ${ }^{21}$ This source also punctuates clauses with Glossenkeile, and these should not be interpreted as correction marks.

16 A. Gianto, 'Amarna Lexicography: The Glosses in the Byblos Letters', SEL 12 (1995), pp. 65$73(67-72)$.

17 K. van der Toorn, 'Cuneiform Documents from Syria-Palestine: Texts, Scribes, and Schools', ZDPV 116 (2000), pp. 97-113 (104).

18 J. Huehnegard, 'Ugaritic Words in Syllabic Texts', in W.G.E. Watson and Nicolas Wyatt (eds.), Handbook of Ugaritic Studies (HdO, 39, Leiden: Brill, 1999) pp. 134-139 (137-138).

19 The mark is a small vertical wedge, similar to the Ugaritic word-divider, with a horizontal wedge on top of it. See RS $24.252 \ln .2=K T U$ 1.08.2 and RS $24.293 \ln .18=K T U 1.133 .18$ with discussion in D. Pardee, Les textes para-mythologiques: 24e campagne (1961). Ras ShamraOugarit IV (Mémoire, 77, Paris: Editions recherche sur les civilisations, 1988) pp. 76-78, 156; J. Tropper, Ugaritische Grammatik: zweite, stark überarbeitete und erweiterte Auflage (АОАT, 273, Münster: Ugarit-Verlag, 2012) § 21.365.

20 J.T. Milik, Qumrân grotte 4 (vol. II, DJD VI, Oxford: Clarendon Press, 1977) p. 88 explains, "à ma connaissance, c' est le seul exemple de ce genre d' interponction dans les manuscripts de Qumrân, au moins dans ceux en écriture araméenne". See also E. Tov, Scribal Practices and Approaches Reflected in the Texts Found in the Judean Desert (STDJ, 54, Leiden: Brill, 2004) p. 138.

21 C.H. Gordon, 'The Aramaic Incantation in Cuneiform', $A f O 12$ (1937), pp. 105-117; B. Landsberger, “Zu Den Aramäischen Beschwörungen in Keilschrift," AfO 12 (1937), pp. 247-257. 
The dots in p. 23141 appear to function differently than the Glossenkeile found at el Amarna and Ugarit, or the dots on $4 \mathrm{Q} 156$ and $T U$ no. 58 , though they coincidentally share similarities with the Ugaritic correction mark. Because the dots on p. 23141 follow a correction, it is reasonable to assume that they are editorial marks used to indicate a secondary (or tertiary) replacement in the text. ${ }^{22}$ As such, they represent a previously unknown Aramaic scribal technique from the Persian period.

One is tempted to suggest, based on the multicultural context of Persian period Egypt, that these dots were borrowed from another scribal culture practiced in Egypt, but the data argues against such a claim. There is no evidence, to my knowledge, of the use of similar dots in contemporary Hieratic or Demotic Egyptian scripts. Sub-linear dots may be used in phonetic or orthographic ways in Demotic script, but there are no vertically aligned dots. ${ }^{23}$ Furthermore, contact between Greek speakers and Aramaic writers is known to have occurred in Egypt during the Persian period, ${ }^{24}$ and dots have a long history in Greek and related sources. In early Greek and Linear в inscriptions two vertically aligned dots are used as a word divider, much like that from Tell Fekherye. ${ }^{25}$ Later Greek manuscripts occasionally used expunging or cancellation dots to identify scribal corrections. In some cases, these dots were used on either side of a cancellation, resembling the form, though not the function, of the dots on p. $23141 .{ }^{26}$ Manuscripts from the Dead Sea Scrolls also used cancellation dots, even on either side of a correction. ${ }^{27}$ While expunging/cancellation dots are editorial scribal marks, their function indicates the opposite of what the dots on p. 23141 seem to indicate, namely, a replacement in the text rather than a deletion.

22 It is difficult to determine if the correction is made by the same or a different writer, but the broad-edge of the reed pen of the dots, the marginal 1 , and the original 1 are all the same width (c. $2.2 \mathrm{~mm}$ ), and the oblique angle of the stylus' chiselled edge is nearly identical on all of these marks and letters. For a discussion of the use of calligraphic features to analyse the Elephantine papyri, see Daniels, 'A Calligraphic Approach to Aramaic Paleography', pp. $55^{-68}$.

23 See O. El-Aguizy, A Palaeographical Study of Demotic Papyri in the Cairo Museum from the Reign of King Taharka to the End of the Ptolemaic Period (684-30 в.c.) (Mémoires, 113, Le Caire: Institut français d' archéologie orientale, 1998) p. 237.

24 See, e.g., the Ahiqar Palimpsest, which is an import and export account of Ionian and Phoenician ships (TAD D.3.7).

25 E.G. Turner and P.J. Parsons, Greek Manuscripts of the Ancient World (2nd rev. ed., Bulletin Supplement, 46, London: Institute of Classical Studies, University of London, 1987) §9.

26 Turner and Parsons, Greek Manuscripts, $\$ 18$.

27 Tov, Scribal Practices, pp. $361-365$. 
It has been shown that the dots on p. 23141 were not borrowed from a scribal culture practiced in first-millennium Egypt, but it is possible that the practice of using dots derives from contact between first-millennium Aramaic and Akkadian writers. In the Persian period, Aramaic continued to adopt Akkadian loanwords, ${ }^{28}$ and the two scribal cultures remained in close contact in Mesopotamia. First-millennium Akkadian scribes continued to use the Glossenkeile in complex ways. As in the earlier el Amarna letters, they were used to provide alternative or variant readings - even for a variant of one sign, ${ }^{29} \mathrm{but}$ they also became the notation for line breaks in a copied manuscript. ${ }^{30}$ In the first millennium, the Glossenkeil or a similarly written KÚR sign appears in the left margin of a number of tablets, ${ }^{31}$ and indicates a correction to a spelling error in the line. ${ }^{32}$ The reason for using KÚR rather than erasing and correcting the error remains unknown, but only the correct sign, without the erroneous reading, is given when KÚR appears. ${ }^{33}$ Therefore, it could indicate that a copyist has corrected his Vorlage. While the dots on p. 23141 are similar in form to the Glossenkeil or KÚ R sign, they remain distinct in function. The Glossenkeile never appear to indicate a simplistic orthographic correction. Akkadian misspellings (i.e. the impression of an incorrect or unintended sign) were frequently erased by smoothing the clay or wax medium and rewriting the sign. While the Kú $\mathrm{R}$ sign can be used to indicate an orthographic change, it never appears as a pair of signs. It also sits in the left margin in which the error occurs and not next to the correction. So while the dots on p. 23141 resemble the form of Glossenkeile and indicate an orthographic error, as can the KÚR sign, the Aramaic dots appear in a pair standing on either side of a correct letter, and at the point in the line where the correction occurs.

28 S.A. Kaufman, Akkadian Influences on Aramaic (Assyriological Studies, 19, Chicago: Oriental Institute, 1974), pp. 156-16o.

29 See in general, J. Krecher, 'Glossen', in E. Ebeling and E. Weidner (eds.), Reallexikon der Assyriologie (3, Berlin: de Gruyter, 1971) pp. 431-440 (esp. 435).

$30 \quad$ W.R. Mayer, 'Das Ritual "KAR" 26 mit dem Gebet "Marduk 24", Or 68 (1999), pp. 145-163 (147). In the Late Babylonian commentary tradition, it functioned as a "separating sign" (Trennungszeichen), see J.Z. Wee, 'A Late Babylonian Astral Commentary on Marduk's Address to the Demons', JNES 75 (2016), pp. 127-167 (133).

31 Krecher, 'Glossen,' 439.

32 W.G. Lambert, 'The Hymn to the Queen of Nippur', in G. van Driel et al. (eds.), Zikir Šumim: Assyriological Studies Presented to F.R. Kraus on the Occasion of His Seventieth Birthday (Studia Francisci Scholten Memoriae Dicata 5, Leiden: Brill, 1982) pp. 173-218 (216).

33 See for example, Ms. Rm II 164+79-7-8, 56 ln. iv.24 in Lambert, 'The Hymn to the Queen of Nippur', p. 188. 
In conclusion, the aligned dots on either side of a waw in the right margin of p. 23141 appear to correct a single letter at the end of a word. These dots take the place of expunging the entire word and rewriting it in the margin or interlinear space, as Aramaic corrections were more commonly made. As fragments from this Aramaic box are joined to published documents or to other fragments, perhaps the context in which these editorial dots were used will come into better focus. Until then, this new fragment stands as evidence for the earliest use of two vertically aligned dots in Aramaic as editorial marks for a single letter, and it sheds new light on Aramaic scribal techniques in the Persian period. 